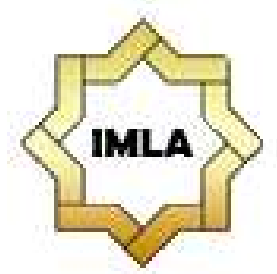

Al-Ta'rib

Jurnal Ilmiah Program Studi Pendidikan Bahasa Arab

IAIN Palangka Raya

Vol. 9, No. 1, June 2021, 67-84

p-ISSN 2354-5887 | e-ISSN 2655-5867

DOI: https://doi.org/10.23971/altarib.v9i1.2584

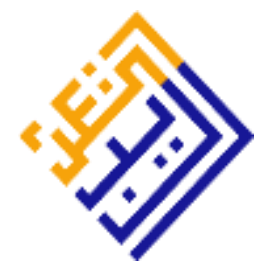

\title{
THE VALUES OF INTEGRATION-INTERCONNECTION IN THE MATERIAL OF ARABIC TEXTBOOK FOR ISLAMIC SENIOR HIGH SCHOOL IN INDONESIA
}

\author{
Muhammad Sya'dullah Fauzi ${ }^{1}$, Zaimatuz Zakiyah ${ }^{2}$ \\ 1,2Universitas Islam Negeri Sunan Kalijaga Yogyakarta, Indonesia \\ E-mail: fauzisadullah97@gmail.com
}

\begin{abstract}
As one of the scientific disciplines in the sociolinguistic field, Arabic is often only fixated on the concept of language without involving other scientific studies, thus giving birth to Arabic learners who are less responsive to the times. This study aims to analyze the values of integration-interconnection contained in the material in the Arabic textbook class XII Islamic Senior High School published by the Indonesian Ministry of Religion, supported by other relevant documents using a literature study. The data collected in the field were analyzed using descriptive-qualitative. This study indicated that the five chapters has already contained the value of integrationinterconnection between religious, scientific, and social sciences. However, there were no value in scientific knowledge found in Chapter II and III. Also, the result of this study needed to be emphasized the application of the value of integrationinterconnection in Arabic learning. It is not enough to rely only on textbooks alone, but it also requires the presence of teachers who participate in extracting other scientific values. The results are expected to contribute to improving the concept of Arabic textbooks, which contain the value of integration-interconnection. Further research is expected to explore the value of integration-interconnection at every level of education. It is highly expected that this will create Arabic language learning that can meet other scientific disciplines.
\end{abstract}

Keywords: Integration-Interconnection; Material; Arabic Textbook

\section{Abstrak}

Sebagai salah satu disiplin keilmuan dalam bidang sosial-kebahasaan, Bahasa Arab seringkali hanya terpaku pada konsep tentang kebahasaan saja tanpa melibatkan kajian keilmuan yang lain, sehingga melahirkan pembelajar-pembelajar bahasa Arab yang kurang responsif terhadap perkembangan zaman. Penelitian ini bertujuan untuk menganalisis nilai-nilai integrasi-interkoneksi yang terdapat dalam materi pada buku ajar bahasa Arab kelas XII Madrasah Aliyah terbitan Kementrian Agama RI yang didukung dengan dokumen-dokumen relevan lainnya dengan menggunakan metode penelitian jenis studi pustaka. Data yang terkumpul kemudian dianalisis menggunakan kualitatif deskriptif. Hasil dari penelitian ini menunjukkan bahwa kelima bab sudah memuat nilai integrasi-interkoneksi antara keilmuan agama, sains dan sosial. Hanya saja, peneliti tidak menemukan adanya nilai 
pengetahuan sains dalam bab II dan III. Selain itu, yang perlu ditekankan dari hasil penelitian ini adalah bahwa penerapan nilai integrasi-interkoneksi dalam pembelajaran bahasa Arab tidak cukup hanya mengandalkan buku ajar saja, tetapi juga membutuhkan kehadiran guru yang turut serta dalam penggalian nilai-nilai keilmuan yang lain. Hasil dari penelitian ini diharapkan dapat memberikan sumbangsih terhadap perbaikan konsep buku ajar bahasa Arab yang memuat nilai integrasi-interkoneksi. Penelitian selajutnya diharapkan mampu menggali nilai-nilai integrasi-interkoneksi di setiap jenjang pendidikan. Sehingga dapat menciptakan pembelajaran bahasa Arab yang mampu bertegur sapa dengan disiplin keilmuan yang lainnya.

Kata Kunci: Buku Ajar; Integrasi-Interkoneksi; Materi; Buku Ajar Bahasa Arab

\section{Introduction}

Islamic science today tends to experience a dichotomy between religious science and general science. Karwadi (2008), in his scientific work, writes that this is an implication of some people opinion towards these two sciences. They view that the two have different goals, causing debate among their supporters (Karwadi, 2008). According to Rahman, this dichotomic view can cause the decline in the rule of science in the Islamic world (Rahman, 1984, p. 33). Muslih views that this has even led to lags in various sectors of life, and conceptually, the development of science is positioned outside the realm of religion and vice versa (Muslih, 2017). It is because general science is deemed no longer essential and does not need to be studied. It raises anxiety among Muslim thinkers and intellectuals.

The integration-interconnection paradigm exists to open dialogue between scholars so that the scientific dichotomy problem can be resolved. The concept and practice of integration-interconnection are needed to narrow the space of dualism or dichotomy of science that separates general education from religious education, impacting the separation of religious consciousness and general knowledge. They can be seen at the operational level, where there is a separation between madrasas and schools, general subjects and religious subjects, the Faculty of Religion and the General faculty (Machali, 2015). This paradigm demands scientific studies that previously stood on their own to be interlinked and integrated, both religious and scientific and technological as well as social sciences and humanities.

Noor and Adisucipto said that in a learning process, a religious approach is fundamental to do so that there is no dichotomy between the cultural values of science so that students can believe in, understand, and appreciate science as a whole (Noor \& Adisucipto, n.d.). Therefore, learning Arabic as much as possible should be poured into the values of interconnection-integration (Aminuddin, 2010), given that Arabic, which is one of the scientific disciplines in the sociolinguistic field, often stands alone without touching other scientific disciplines. Arabic studies are only fixated on the concept of language without involving another study. It is feared that it will give birth to Arabic learners who are less responsive to the increasingly rapid time. For this reason, students are equipped with the ability to be creative and adaptable so that they can position themselves for changes (Tolinggi, 2020).

However, Arabic is a frightening specter and challenging to conquer. The main problem stems from the unavailability of teaching materials suitable for 
student conditions (Jamil \& Agung, 2019). One of the efforts to realize Arabic learning, which contains the value of integration-interconnection, is compiling Arabic textbooks with integration-interconnection values. Thus, Arabic learning will become a language study containing the value of scientific and religious knowledge. Roviin quotes Muslich that textbooks are mandatory manuals for students and teachers to expedite the learning process and are tools for students to understand and learn about the world outside (Roviin, 2018). Ramah \& Rohman (2018) explains that textbooks affect knowledge because textbooks contain learning material: the knowledge, behavior, and skills, and students must learn them to achieve the set competency standards (Zamzami \& Syamsiyah, 2020). Therefore, textbooks have an essential role in achieving a learning process (Amalia, 2017).

Among the Arabic textbooks circulating in Indonesia, the Arabic language books published by the Ministry of Religion are the most widely used in educational institutions and a barometer for other textbooks. For this reason, researchers are interested in examining the values of integration-interconnection contained in the textbook published by Ministry of Religion (Sulistiyo et al., 2020). It is in line with the mandate from the Indonesian government to teachers to incorporate moral values into subjects (Sulistiyo et al., 2020). The teacher is asked to organize learning and develop material on the topic (Banegas, 2012). Therefore, how to teach language to students (Musthofa \& Rosyadi, 2020) and how to analyze student needs (Bogolepova, 2016) are important things that teachers must master. Furthermore, teachers are also asked to increase self-esteem and self-confidence and to develop personal and professionalism to help themselves and others (Tomlinson, 2012).

After tracing several kinds of literature, the researcher found several scientific papers relevant to the theme of this research, including a scientific article entitled "Pengembangan Buku Ajar Bahasa Arab Berbasis Integrasi-Interkoneksi untuk Mahasiswa Baru UIN Sunan Kalijaga Yogyakarta" (Rodli, 2017). The results found from this scientific paper showed that the response of the new students of UIN Sunan Kalijaga Yogyakarta to this integration-interconnection-based Arabic textbook was 4.045 (reasonable) in the learning aspect, 4.125 (reasonable) in the content/material aspect, 3,975 (reasonable) in the display aspect, and 4.095 (reasonable) in the presentation aspect. Rodli's writing and ours have similarities in the research background, namely the availability of Arabic language textbooks based on integration-interconnection, which can accommodate the needs of learners. The only difference is on the research method used. Rodli's study used the research and development method, whereas we use the library research method. This research aims to develop Arabic language teaching materials intended for new students of UIN Sunan Kalijaga Yogyakarta. At the same time, this study also aims to analyze the values of integration-interconnection in class XII Arabic teaching materials published by Indonesian Ministry of Religion.

The second literature was articles compiled by Lailatul Aslamiyah, et al. in 2017 with the title "Pengembangan Media Pembelajaran Komik Fisika Berbasis Integrasi-Interkoneksi Nilai-Nilai Al-Quran" (Aslamiyah et al., 2017). This research showed that comic media was deemed appropriate by material experts and media experts. Students also gave excellent responses because comics were easier to use 
and understand when compared to books. This study showed similarities and differences with our research. The basic approach used was integrativeinterconnective based. The difference found in their study was the aim to determine the characteristics, feasibility, student responses, and effectiveness of the developed comic me. In contrast, this study aims to analyze the values of integration-interconnection in language teaching materials of Arabic textbook for class XII Islamic high school. The research method is also different. This previous research used the method of research and development, while we use the library research method. Another difference is that the media was developed in learning Physics, while the teaching materials used to analyze in this study is in Arabic learning.

Third, the article written by Fikryyah Dwi Cahyani entitled, "Pengembangan Buku Ajar Akuntansi Berbasis Integrasi-Interkoneksi untuk Kelas XI IPS di MAN 3 Malang" (Cahyani, 2016). The results indicated that the developed textbooks were valid and suitable for use. Moreover, textbooks that were developed effectively increased student motivation and learning outcomes, indicated by the differences before and after treatment. This research has similarities and differences with our research. The similarities are based on integration-interconnection. The difference is in the aim to produce accounting textbooks as alternative teaching material for teachers and students and determine their effectiveness, whereas our research aims to analyze the values of integration-interconnection in class XII Arabic teaching materials. It had implications for the different research methods used. The previous study used research and development method that was modified and referred to the Borg and Gall model, whereas we use literature study method.

Article by Hamdan Sugilar, et al. written in 2019 with the title "Integrasi, Interkoneksi Matematika Agama dan Budaya" (Sugilar et al., 2019) was the fourth to review. The results of this study pointed that the principle of integration consisting of complete collaboration, reflective action, external support, continuous processes, focused programming, problem-solving, and teachers were the keys. With this method, students understood that mathematics was beneficial and very close to everyday life. This method was presented through a collaboration between fields by formulating material that can be integrated with all subjects and experiences. Interconnection was done by linking mathematical material to other fields or to mathematics itself. Integration is more about blending mathematics in other fields, and this research has similarities with other previously conducted research. The equation was based on integrationinterconnection and used literature study method, and the difference lies in the research objectives. They aimed to explain the principles, theories, and methods of integration and interconnection in mathematics, while our study aims to analyze the values of integration-interconnection in class XII Arabic teaching materials published by Indonesian Ministry of Religion.

Fifth, an article written by M. Amin Abdullah and Waryani Fajar Riyanto entitled "Integrasi-Interkoneksi Psikologi: Implementasinya pada Penyusunan Buku Ajar di Program Studi Psikologi Fakultas Ilmu Sosial dan Humaniora UIN Sunan Kalijaga Yogyakarta" (Abdullah \& Riyanto, 2015). The results of this study showed that Psychological Integration-Interconnection or abbreviated as "Int-I-P" was trisectionalizing three schools of psychology, namely Islamic Psychology, Islamized 
Psychology, and Islamic Psychology of 'Religion'. Abdullah called the IntegrationInterconnection School of Psychology the fourth school in psychology. Therefore, the preparation of textbooks must refer to the four types of psychology school models. This research has similarities with ours which is the equation discussing integration-interconnection. The difference is on determining the implementation of integration-interconnection in the preparation of textbooks in the Psychology department. In contrast, our research aims to analyze the values of integrationinterconnection in class XII Arabic teaching materials published by Indonesian Ministry of Religion.

Integration-interconnection has been discussued in various articles. However, in search of several kinds of literature, no research analyzes the integration-interconnection values contained in the material in the XII class Arabic textbook published by Ministry of Religion of the Republic of Indonesia. Therefore, we conduct a literature study by analyzing the values of integrationinterconnection in the book. The study results are expected to contribute to improving the concept of learning Arabic, especially in the concept of Arabic textbooks, to express the value of integration-interconnection. It is hoped that this will create Arabic language learning that can meet other scientific disciplines and give birth to Arabic learners who are responsive to the time changing.

\section{Method}

The approach used in this research was a qualitative approach intended to understand the phenomena observed with specific natural contexts by utilizing various research methods (Moleong, 2007, p. 6). The research method used was library research. This study was conducted by collecting data in the library and reading some literature to provide information relevant to the research topic (Sukardi, 2003, pp. 34-35). The data were collected by using the documentation method, where the data on existing variables was obtained from various sources, such as notes, transcripts, books, newspapers, magazines, inscriptions, meeting minutes, and agendas (Arikunto, 2010, p. 274). Afterwards, the data were analyzed using descriptive-qualitative analysis, a way of concluding an object, condition, system of thought, a systematic factual description, and its relationship to the phenomenon being analyzed (Nazir, 1998, p. 63). The analysis used in this study referred to the interconnection-integration model proposed by Amin Abdullah, which sought to integrate and interconnect religious values with natural science, social and humanity values (Amin \& et al., 2007, p. 53).

\section{Results and Discussion \\ Basic Concepts of the Integration-Interconnection Paradigm}

In Indonesian, integration is defined as unification to become a complete and unified unity (Bahasa, 2008, p. 594), while interconnection is often defined as a connection or relationship between oneself (Http://Kbbi.Web.Id/Interkoneksi, n.d.). Scientific discourse, both religious and general sciences, must be studied in an integrated manner as much as possible. An integrative scientific paradigm does not mean incorporating various scientific disciplines into one form. However, the characters, features, and nature of these inter-disciplines are integrated into a 
unitary material-spiritual dimension, intellect-revelation, general science-religious sciences, physical-spirituality, and world-hereafter.

Meanwhile, interconnection is the relationship between one knowledge and another due to a relationship that affects each other (Ungguh Muliawan, 2005, p. xii). In simple term, integration can be interpreted as a way of studying one scientific field while still looking at other scientific fields. In other words, interconnection can be defined as the relationship between one scientific field and another.

Amin Abdullah initiated the integration-interconnection paradigm to connect religious science and general science incorporated in the natural sciences, social sciences, and humanities (Amin \& et al., 2007, p. 53). An integrativeinterconnective approach is an approach that seeks mutual respect between general science and religion to be aware of each other's limitations in solving human problems. It will bring forth a collaboration to understand each other's approach and methods of thinking (process and procedure) between these clashes. The integration-interconnection paradigm is not to mix up various scientific fields but to respect each other and make a collaboration between scientific fields.

This paradigm makes three main areas of science: natural sciences, social sciences, and humanities, which no longer regarded stand-alone but will be related to one another (A. Abdullah, 2006, p. 370). The three of them will become increasingly merged even though they will not unite the three, but at least, there will be no more superiority and inferiority in science. Moreover, there will be no more claims to the truth of science so that with this paradigm scientists who pursue this science will also have attitudes and ways of thinking differently from before (Siswanto, 2013). There are at least three main areas of integrationinterconnection, namely: 1) religious science, 2) natural science, 3) social and humanities. The three of them must be related to each other to become a complete building of knowledge.

\section{Arabic Textbook for Class XII Islamic High School}

The Arabic textbook for class XII students, which is the main object of this research, is published by Indonesian Ministry of Religion through Directorate General of Islamic Education according to KMA No. 183 of 2019 concerning the Islamic and Arabic Language Education Curriculum. The characteristics of this book are as follows. First, the book's cover is brown. Second, the writing of Directorate General of Islamic Education in Ministry of Religion of the Republic of Indonesia 2020 as a book publisher is written at the top left of the book cover. Third, the book title is written in the middle, namely Arabic. Fourth, Class XII and Madrasah Aliyah are written on the lower right of the book's cover, which indicates that the book is intended for class XII students. Last, this book contains 91 pages.

The background of this book is the development of science, technology, and communication that changes very quickly and is unpredictable. It is chosen so that students have a strong personality, character and are not uprooted from the nation's cultural roots (Alfiatus \& Barry, 2020, p. ii). Besides, this book is expected to not only equip students with a comprehensive and moderate understanding of religion but also become a reference in thinking, behaving, and acting so that students can adapt and be compatible with the guidance of their time in building 
national civilization (KMA No. 183 Tahun 2019 Tentang Kurikulum PAI Dan Bahasa Arab Pada Madrasah, n.d.).

This book is presented with the following presentation:

1. The initial view of the book consists of an Arabic title page.

2. The first page (1) contains the book's identity.

3. The second page (2) contains Muhammad Ali Ramdhani's foreword, Director General of Islamic Education.

4. On the third and fourth pages ( 3 and 4), transliteration guidelines are written.

5 . On the fifth and sixth pages ( 5 and 6 ), a table of contents is written.

6. The seventh to the thirty-third page (7-83) contains Basic Competencies (Kompetensi Dasar/KD), indicators, concept maps, then continued with the content of Arabic subject matter in the form of Istima', Qira'ah, Qawā'id, Kitābah, Kalām, and closed with conclusion.

7. The end of the book is added with Istima' materials, vocabulary, and references.

8. The exercises for the first semester are on page 44, and for the second semester are on page 74 .

The team drafted the Arabic text for class XII provided the following table of contents to make students find chapters and titles from the book easier.

Table 1.

The List of Material Contents

FOREWORD

ARABIC-LATIN TRANSLITERATION GUIDELINES

TABLE OF CONTENTS

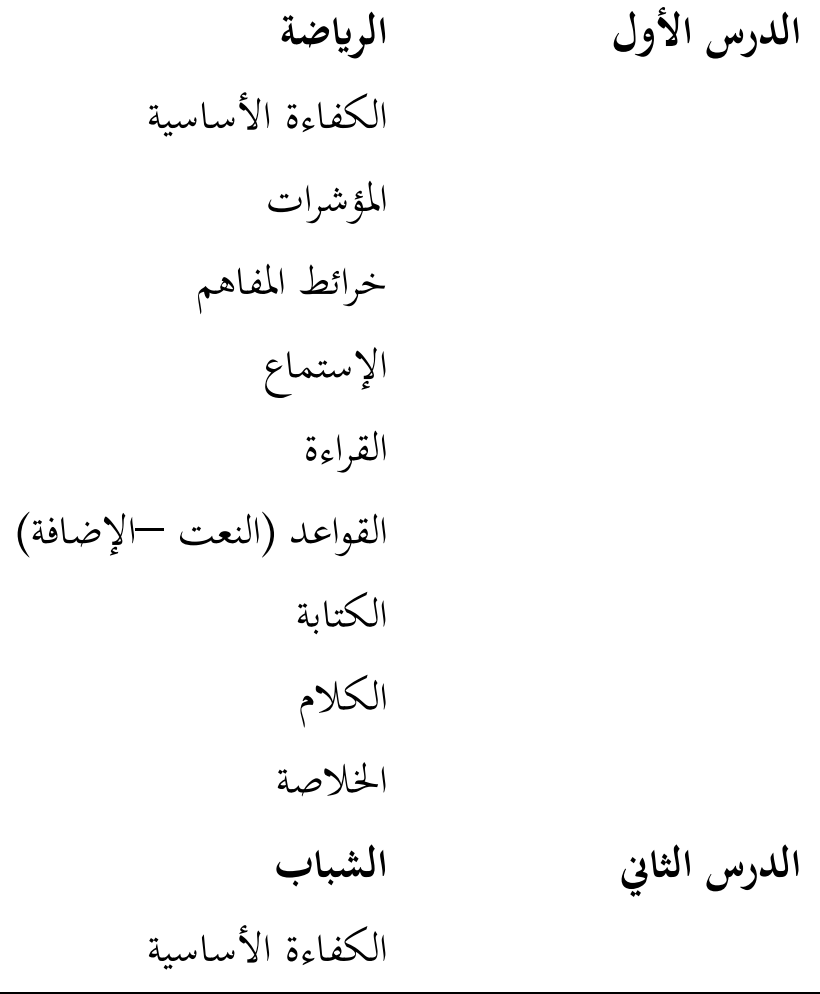

Jurnal Ilmiah Program Studi Pendidikan Bahasa Arab IAIN Palangka Raya Vol. 9, No. 1 /67-84 Al-Ta'rib | p-ISSN 2354-5887 | e-ISSN 2655-5867 


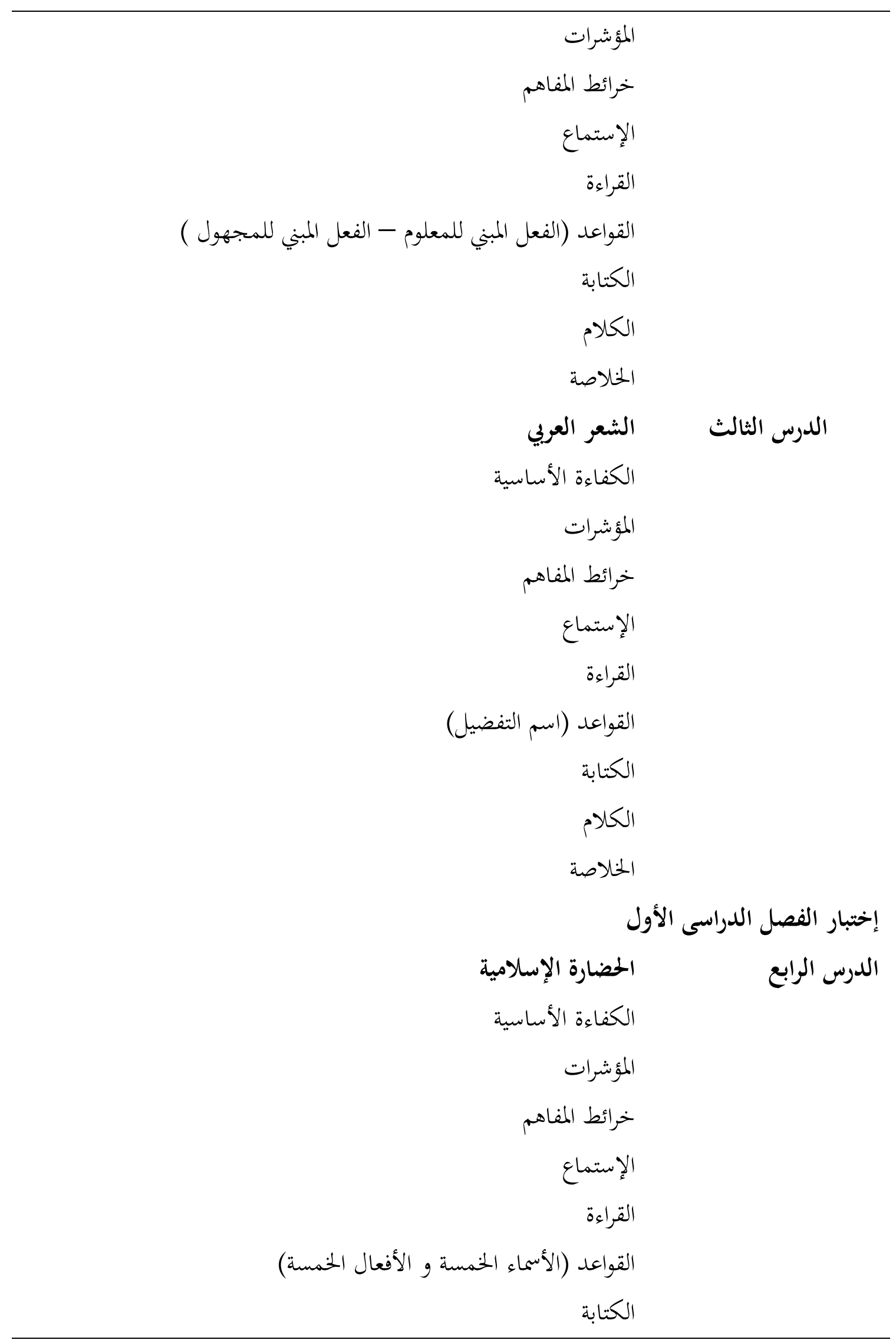




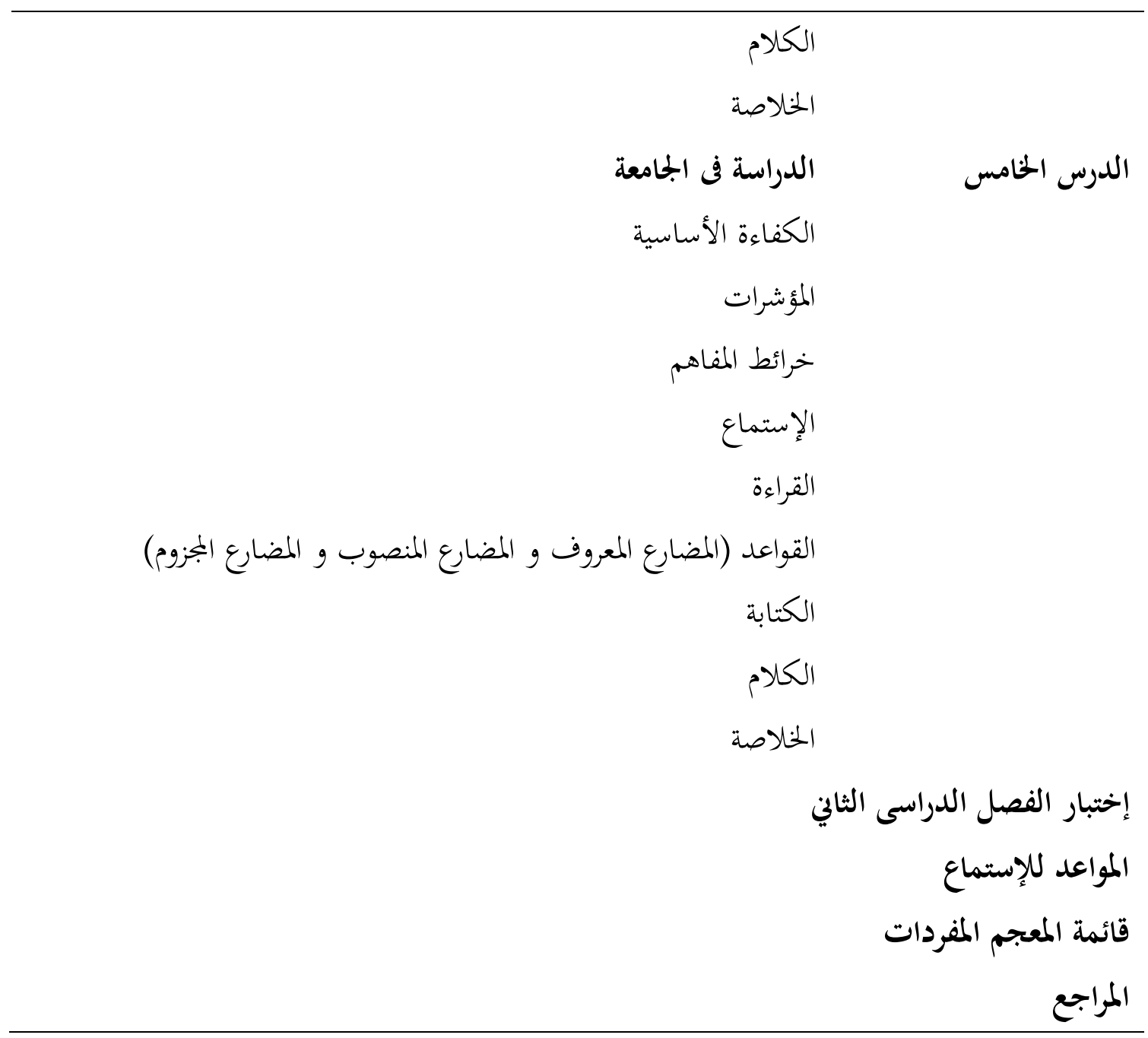

Based on the list of the material contents, the learning materials listed in the Class XII Arabic textbooks published by Directorate General of Islamic Education of Indonesian Ministry of Religion consist of five chapters.

The teaching materials in the book are as follows.

Table 2.

The Content of Teaching Materials

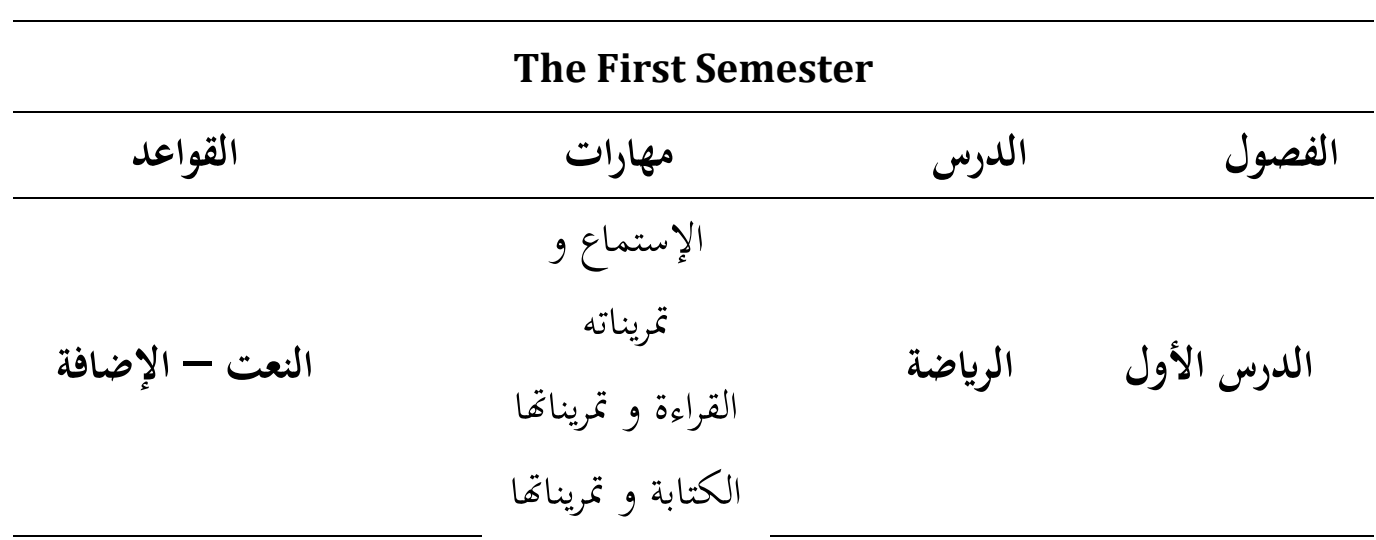

Jurnal Ilmiah Program Studi Pendidikan Bahasa Arab IAIN Palangka Raya Vol. 9, No. 1 /67-84 Al-Ta'rib | p-ISSN 2354-5887 | e-ISSN 2655-5867 


\begin{tabular}{|c|c|c|c|}
\hline & الكلام و تمريناته & & \\
\hline الفعل المبني للمعلوم - الفعل & 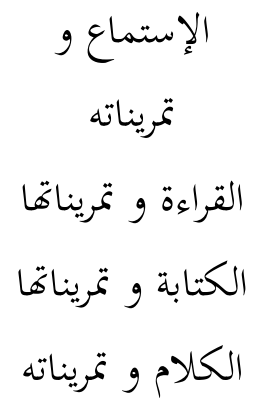 & الشباب & الدرس الثاني \\
\hline اسم التفضيل & القراءة الإستماع و و الكتابة و وتمرينه & الشعر العربي & الدرس الثالث \\
\hline
\end{tabular}

\section{The Second Semester}

\begin{tabular}{|c|c|c|c|}
\hline الأسماء الخمسة و الأفعال & 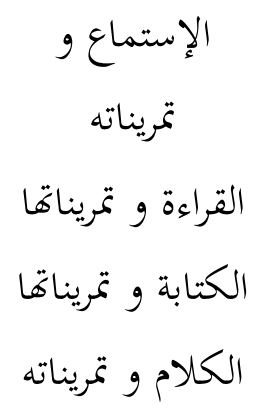 & الحإسارة & الدرس الرابع \\
\hline المضصارع المعروف و المضارع & 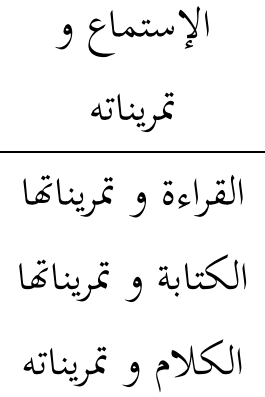 & الدراسة فى الحامعة & الدرس الخامس \\
\hline
\end{tabular}

The Values of Integration-Interconnection in Arabic Textbook for Class XII

Based on the author's analysis of the materials in the Arabic textbook for class XII Islamic Senior High School, the value of integration-interconnection in the aspects of religion, science, and social humanities is as follows. 
Table 3.

The Values of Integration-Interconnection in Arabic Textbook

\begin{tabular}{|c|c|c|c|c|}
\hline No & Chapter & Religious & Science & $\begin{array}{c}\text { Social } \\
\text { Humanities }\end{array}$ \\
\hline 1 & الدرس الأول (الرياضة) & v & v & $\mathrm{v}$ \\
\hline 2 & الدرس الثاني (الشباب) & v & - & v \\
\hline 3 & الدرس الثالث (الشعر العربي) & v & - & v \\
\hline 4 & (الحضارة الإسلامية) الرابع & v & v & v \\
\hline 5 & (الدراسة في الجامعة الخامس) & v & v & v \\
\hline
\end{tabular}

Chapter I (الدرس الأول)

\section{Religious Scientific Value}

The first chapter of this Class XII Arabic textbook has the theme الرياضة, which means "sport". Based on the material analysis carried out, the religious and scientific values in this theme include the importance of physical health. Islam does not only teach its followers to maintain spiritual health but also to maintain physical health. The Prophet has mentioned the importance of maintaining physical health in his hadith, which reads:

$$
\text { نِعْمَتَانِ مَغْبُونْ فِيهِمَا كَثِيرٌ مِنَ النَّاسِ ، الصِّحَّةُ وَالْفَرَاغُ }
$$

It means: "There are two blessings that many people are deceived into losing: health and free time." (Narrated by Bukhari). Apart from that, the Prophet also said that "a strong believer is better and more loved by Allah than a weak believer" (Narrated by Muslim)

\section{Natural Science Value}

Based on the results of the material analysis, there is a material that contains natural science values. Among them are in the القراءة material entitled الرياضة In the reading text, the benefits of exercise are explained. It sounds as follows:

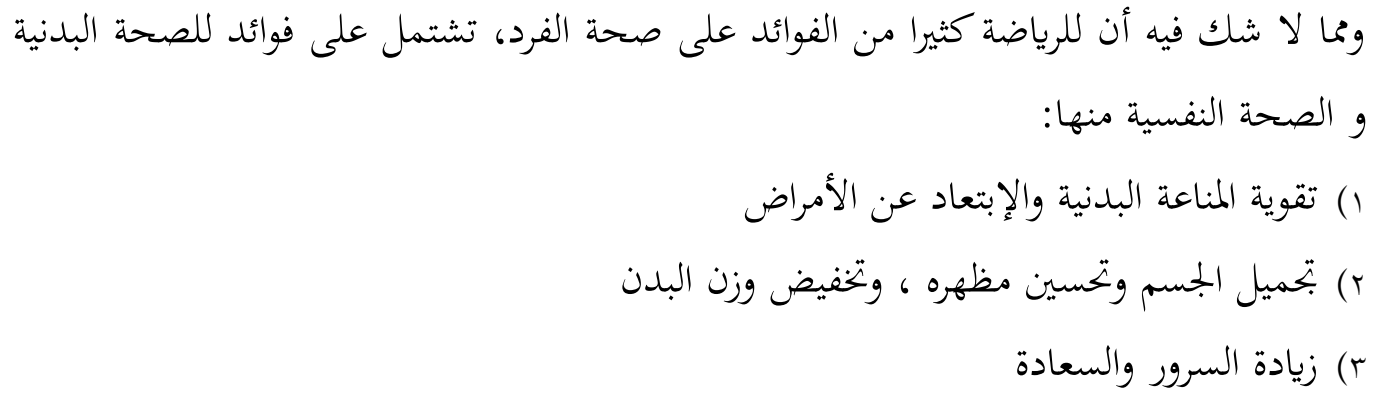




$$
\text { ـ) تقليل القلق و تسهيل النوم التفكير والتركيز وترقية الثقة بالنفس }
$$

The benefits of exercise are explained in the reading text, such as keeping away from various diseases, beautifying the physical form, increasing happiness, reducing anxiety levels, making it easier to sleep, strengthening the mind and increasing self-confidence.

To explain the benefits of this sport, naturally, the evidence must be explained scientifically to show development in scientific science. In this case, teachers are expected to be able to explore this material further. Therefore, it is expected that at the same time, it can provide scientific knowledge in learning Arabic.

\section{Social Science and Humanity Value}

Social and humanities values in this chapter are contained in the reading text about الرياضة, when explaining that sports are divided into two types: individual sports and group/team sports. When explaining team sports, the teacher can tell the students that working together in team is needed. In this case, the value of cooperation is also considered very important in social life.

Besides, social values in this chapter can be found in the material كلام. There are instructions for students to practice conversations with their friends.

$$
\text { تبادل الحوار مع زميلك فيه العبارات التالية! }
$$

Conversations between students must be carried out under correct communication ethics. Here the teacher can direct students to communicate well. For this reason, in this chapter, it can be said that there is already an integrationinterconnection value between religious science and general science.

\section{Chapter II (الدرس الثاني)}

\section{Religious Scientific Value}

The theme in this chapter is about الشباب, which means youth. The choice of the theme is correct because this textbook is presented for class XII, which is suitable for adolescents who will reach adulthood. The discussion about youth becomes essential because adolescence is a crucial period in human life. Adolescence is a time when a person's emotions tend to be unstable. Here, a touch of religion is needed so that adolescents are not spent with things prohibited by religion.

Among the religious, scientific values in this chapter is a reading text entitled الشباب المتنائل, which means optimistic youth. This text explains that the youth must be optimistic because optimism can generate positive thoughts and be happy and grateful. It is aligned with verse 7 in Surah Ibrahim which is being confident and encouraging oneself to realize dreams. Furthermore, this is also following verse 11 in Surah al Mujadilah which is being patient and honest. 
The presentation of the material is in under religious values, especially with the existing arguments of al-Qur'an.

\section{Natural Science Value}

The researchers have not found any significant scientific value in this chapter.

\section{Social Value and Humanity Value}

In the الكلام material of this chapter, students are asked to make short conversations by choosing three themes. Among them are "البتمع كيف يعيش سالم في". In this chosen theme, students are expected to know how young people get along in society properly and correctly. It is the reason that in this material, there are social values that can be extracted.

\section{Chapter III (الدرس الثالث)}

\section{Religious scientific values}

This chapter has the theme of الشعر العربي or Arabic literature. The reading text contained in the القراءة material entitled الشعر العربي العربي among them explains the biography of al-Bushiry the author of qasida burdah. The value of religious knowledge that can be taken from the reading text is about love for the Prophet. Even in the الكلام material, there is an assignment for students to talk about حب رسول الله. Giving assignments like this will undoubtedly instill the importance of loving the Prophet in students by studying his example.

\section{Natural Science Value}

Specifically, researchers have not found the value of natural science or natural science in this third chapter.

\section{Social Science and Humanities Value}

Selection of the theme الشعر العربي in this chapter certainly requires teachers to be able to explain Arabic literature. Although not in-depth, teachers are expected to make students understand about the cultural and social culture of the Arab community and how most Arab people were enthusiastic about poetry in that period. Consequently, this gave students insight into the social life of the Arab community in that period.

\section{Chapter IV (الدرس الرابع)}

\section{Religious Scientific Value}

This chapter carries the theme of الحضارة الإسلامية, which means Islamic civilization. In this chapter, students learn about the history of Islamic civilization briefly, especially those in the reading text تاريخ الحضارة الإسلامية in the material of القراءة. The students are expected to take exemplary values that made Islam the center of civilization in that period, which is the love of the community for religious and general sciences and the high level of literacy in society. It is naturally following the scientific values of Islam.

\section{Natural Science Value}

Science developed rapidly at the peak of the glory of Islam, which was the center of world civilization at that time. Scientific development is not only in religious knowledge but also in other scientific sciences, including chemistry, 
astronomy, and medicine. Delivering the suitable material in this chapter can instill student's motivation to study general science and not only religious science.

\section{Social Sciences and Humanities Value}

Studying history also means studying social life in the past. The presence of teachers to convey social values in this chapter is also crucial in providing knowledge to students about social life when Islam became the center of world civilization. It is expected to provide adequate social role models for students to be emulated in the present.

\section{Chapter V (الدرس الخامس)}

\section{Religious Scientific Value}

The theme chosen in this chapter is الدراسة في الجامعة, which means "studying in college". The religious scientific values contained in this chapter are about the importance of seeking knowledge. Students are expected to be motivated to study hard to continue their studies to higher education. The choice of this theme can be said to be appropriate because the presentation of this material is for class XII students who are expected to continue their study to a higher level.

Instilling a love for science that is implemented by studying diligently is one of the values of religious scholarship. It is under the hadith of the Prophet that seeking knowledge is obligatory for every Muslim.

\section{Natural Science Value}

In this chapter, there are values of scientific knowledge that can be taken. Among them are in the reading text entitled الدراسة في الجامعة. In this text, students can add insight into life as closely related to thinking scientifically and empirically. A student life is closely related to the use of technology, and teachers can convey the scientific values to students. Although not too specific, instilling this knowledge can encourage students about the importance of technology mastery and scientific thinking for a student life.

\section{Social Science and Humanities Value}

Apart from providing knowledge about religion and science, this chapter also provides social knowledge. Students can find out about social lifestyles for students. The reading text explains that a student should not be anti-social in life and should not be too dependent on others. Students are expected to be independent with their respective responsibilities. It is the social value found within this last chapter.

\section{Conclusion}

Arabic has a very strategic role in human life. Learning Arabic today is not adequate by only learning the language. More than that, it is expected that learning Arabic will also provide the values of other scientific disciplines. Textbooks containing integration-interconnection values are expected to make Arabic learning not become monodisciplinary without addressing other scientific disciplines. For this reason, this research is considered necessary because it tries to analyze the value of integration-interconnection of materials in Arabic teaching materials so that Arabic learning is no longer regarded as monodisciplinary.

Based on the material analysis in the XII grade Arabic textbook, the five chapters contained the value of integration-interconnection between religious, 
scientific, and social science. However, in Chapter II and III, the researcher did not find any value in scientific knowledge. The results of this study also need to be emphasized because the application of the value of integration-interconnection in Arabic learning cannot only rely on textbooks but also requires the presence of teachers who participate in extracting other scientific values.

\section{References}

Abdullah, A. (2006). Islamic Studies Di Perguruan Tinggi: Pendekatan IntegratifInterkonektif. Pustaka Pelajar.

Abdullah, M. A., \& Riyanto, W. F. (2015). Integrasi-Interkoneksi Psikologi (Implementasi Bagi Penyusunan Buku Ajar di Program Studi Psikologi Fakultas Ilmu Sosial dan Humaniora UIN Sunan Kalijaga Yogyakarta. Jurnal Psikologi Integratif, 2(1), Article 1. https://doi.org/10.14421/jpsi.2014.\%x

Alfiatus, S., \& Barry, M. Y. F. (2020). Bahasa Arab Kelas XII. Direktorat Jenderal Pendidikan Islam Kementrian Agama RI.

Amalia, A. (2017). Analisis Gradasi Materi Saraf Dalam Buku Belajar Tasrif Sistem 20 Jam Karya KH. Aceng Zakaria. Al Mahāra: Jurnal Pendidikan Bahasa Arab, 3(1), 102-123. https://doi.org/10.14421/almahara.2017.031-06

Amin, A., \& et.al. (2007). Islamic Studie: Dalam Paradigma Integrasi Interkoneksi (Sebuah Antologi). Penerbit Suka Press.

Aminuddin, L. H. (2010). INTEGRASI ILMU DAN AGAMA: Studi Atas Paradigma Integratif Interkonektif UIN Sunan Kalijaga Yogjakarta. Kodifikasia: Jurnal Penelitian Islam, 4(1), 1-34. https://doi.org/10.21154/kodifikasia.v4i1.746

Arikunto, S. (2010). Prosedur Penelitian: Suatu Pendekatan Praktik. PT Rineka Cipta.

Aslamiyah, L., Masturi, M., \& Nugroho, S. E. (2017). Pengembangan Media Pembelajaran Komik Fisika Berbasis Integrasi-Interkoneksi Nilai-Nilai Alquran. UPEJ Unnes Physics Education Journal, 6(3), 44-52. https://doi.org/10.15294/upej.v6i3.19271

Bahasa, P. (2008). Kamus Bahasa Indonesia. Pusat Bahasa Departemen Pendidikan Nasional.

Banegas, D. (2012). Teacher-developed materials for the integration of content and language: An action research project in Argentina. Language Teaching, 45. https://doi.org/10.1017/S0261444812000109

Bogolepova, S. (2016). Textbook Evaluation as a Means of Discovering Learners' and Teachers' Needs (SSRN Scholarly Paper ID 3061189). Social Science Research Network. https://papers.ssrn.com/abstract=3061189

Cahyani, F. D. (2016). Pengembangan Buku Ajar Akuntansi Berbasis IntegrasiInterkoneksi Untuk Kelas XI IPS di MAN 3 Malang. Journal of Accounting and Business Education, 2(2), Article 2. https://doi.org/10.26675/jabe.v2i2.6059 
Http://kbbi.web.id/interkoneksi. (n.d.).

Jamil, H., \& Agung, N. (2019). Designing The Arabic Learning Book Based on The Hiwar Approach for Non-Arabic Education Program at Muhammadiyah Islamic University of Sinjai (ar). Al-Ta'rib: Jurnal Ilmiah Program Studi Pendidikan Bahasa Arab IAIN Palangka Raya, 7(2), 97-110. https://doi.org/10.23971/altarib.v7i2.1561

KARWADI, -. (2008). Integrasi Paradigma Sains dan Agama dalam Pembelajaran Aqidah (Ketuhanan) (Telaah Teoritis Dari Perspektif Kurikulum Integratif). Jurnal Penelitian Agama, VOL.XVII, NO. 3 SEPTEMBER-DESEMBER 2008. http://digilib.uin-suka.ac.id/8793/

KMA No. 183 Tahun 2019 Tentang Kurikulum PAI dan Bahasa Arab pada Madrasah. (n.d.). Direktorat Jenderal Pendidikan Islam Kementrian Agama RI.

Machali, I. (2015). Pendekatan Integrasi-Interkoneksi dalam Kajian Manajemen dan Kebijakan Pendidikan Islam. El Tarbawi, 8(1), 32-53. https://doi.org/10.20885/tarbawi.vol8.iss1.art3

Moleong, L. (2007). Metode Penelitian Kualitatif. Remaja Rosdakarya.

Muslih, M. (2017). Tren Pengembangan Ilmu di UIN Sunan Kalijaga Yogyakarta. Episteme, 12(1), 103-139.

Musthofa, T., \& Rosyadi, F. I. (2020). Actualization of Behavioral Theory in Learning Arabic Speaking Skills at the Madrasah Aliyah Level. Universal Journal of Educational Research, 8(12A), 7343-7349. https://doi.org/10.13189/ujer.2020.082518

Nazir, M. (1998). Metodologi Penelitian. Grafindo Indonesia.

Noor, F. M., \& Adisucipto, J. M. (n.d.). Integrasi-Interkoneksi Keilmuan Sains dan Islam dalam Proses Pembelajaran Fisika. 10.

Rahman, F. (1984). Islam and Modernity: Transformation of An Intelectual Tradition Chicago. University Press.

Ramah, S., \& Rohman, M. (2018). Analisis Buku Ajar Bahasa Arab Madrasah Aliyah Kurikulum 2013. ARABIYATUNA: Jurnal Bahasa Arab, 2, 141. https://doi.org/10.29240/jba.v2i2.552

Rodli, A. (2017). Pengembangan Buku Ajar Bahasa Arab Berbasis IntegrasiInterkoneksi untuk Mahasiswa Baru UIN Sunan Kalijaga Yogyakarta. Jurnal Pendidikan Madrasah, 2(1), 103-120.

Roviin, R. (2018). Analisis Buku Teks Al-'Arabiyyah li al-Nasyiin Karya Mahmud Ismail Shini, dkk. Jurnal Al Bayan: Jurnal Jurusan Pendidikan Bahasa Arab, 10(1), 36-53. https://doi.org/10.24042/albayan.v10i01.2594

Siswanto, S. (2013). Perspektif Amin Abdullah tentang Integrasi-Interkoneksi dalam Kajian Islam. TEOSOFI: Jurnal Tasawuf Dan Pemikiran Islam, 3(2), 376-409. https://doi.org/10.15642/teosofi.2013.3.2.376-409 
Sugilar, H., Rachmawati, T. K., \& Nuraida, I. (2019). Integrasi interkoneksi matematika agama dan budaya. Jurnal Analisa, 5(2), 189-198. https://doi.org/10.15575/ja.v5i2.6717

Sukardi, H. (2003). Metodologi Penelitian Pendidikan. Bumi Aksara.

Sulistiyo, U., Supiani, S., Kailani, A., \& Lestariyana, R. P. D. (2020). Infusing moral content into primary school English textbooks: A critical discourse analysis. Indonesian Journal of Applied Linguistics, 10(1), 251-260. https://doi.org/10.17509/ijal.v10i1.25067

Tolinggi, S. O. R. (2020). Pengembangan Kurikulum Bahasa Arab Berparadigma Integrasi-Interkoneksi Mengacu KKNI dan SN-DIKTI. Al-Ta'rib: Jurnal Ilmiah Program Studi Pendidikan Bahasa Arab IAIN Palangka Raya, 8(2), 177-200. https://doi.org/10.23971/altarib.v8i2.2104

Tomlinson, B. (2012). Materials development for language learning and teaching. Language Teaching, 45(2), 143-179. https://doi.org/10.1017/S0261444811000528

Ungguh Muliawan, J. (2005). Pendidikan Islam Integratif: Upaya Mengintegrasikan Kembali Dikotomi Ilmu dan Pendidikan Islam. Pustaka Pelajar.

Zamzami, M. I., \& Syamsiyah, D. (2020). The Material Analysis and Learning Method of Nahwu in the Book of Qawa'id Al-Asasiyyah Li Al-Lughah Al'Arabiyyah. Al Mahāra: Jurnal Pendidikan Bahasa Arab, 6(2), 257-278. https://doi.org/10.14421/almahara.2020.062.06

\section{Copyright Notice}

Authors retain copyright and grant the journal right of first publication with the work simultaneously licensed under a Creative Commons Attribution 4.0 International License that allows others to share the work with an acknowledgement of the work's authorship and initial publication in this journal. 
THIS PAGE INTENTIONALLY LEFT BLANK 